\title{
Konservasi DAS (Daerah Aliran Sungai) Dalam Upaya Perlindungan Kawasan Situs Biting Kabupaten Lumajang
}

\author{
Asyhadi Mufsi Batubara \\ Mahasiswa S2 Arkeologi, Universitas Gadjah Mada \\ Email: didi_roten@yahoo.co.id
}

\begin{abstract}
Abstrak: Aliran sungai sebagai sumber kehidupan dan media untuk mensucikan, telah menempatkannya dalam urutan teratas unsur alam yang paling mempengaruhi jalannya perkembangan peradaban manusia. Tidak mengherankan apabila banyak ditemukan bangunan suci dan perbentengan kuno berdekatan dengan aliran sungai. Disamping bernilai manfaat, aliran sungai juga memiliki sisi negatif yang bersifat merusak, sehingga dikhawatirkan akan berdampak buruk pada bangunan suci dan perbentengan yang kini telah menjadi bangunan cagar budaya. Melihat kondisi tersebut dan juga kondisi di lapangan yang cukup mengkhawatirkan, maka perlu dilakukan suatu langkah konservasi DAS (Daerah Aliran Sungai) yang bersifat spesifik untuk menangani situs cagar budaya yang bersinggungan langsung dengan aliran sungai. Kajian ini masih bersifat penelitian awal, sehingga metode yang digunakan bertumpu pada pengamatan dilapangan dan pengkajian dengan menggunakan pendekatan bidang keilmuan lain terkait permasalahan. Harapannya, upaya dan perhatian konservasi situs cagar budaya tidak hanya bertumpu pada objek arkeologisnya saja, akan tetapi juga harus memperhatikan lingkungan sekitar yang juga berpotensi merusak.
\end{abstract}

Kata kunci: Konservasi, sungai, situs.

\begin{abstract}
Watershed, as a life source and cleansing media, has put it into the top of natural elements that influence the human civilizations. It is not surprising then to find many sacred buildings and old forts located near the watershed. Beside its usefulness, watershed hlaso has damaging negative side. It is worried that the watershed will have bad impact on sacred buildings and forts that nowadays have turned into cultural heritage. Looking at that alarming condition, conservation for watershed has to be specific in directly handling cultural heritage that located near the watershed. It is still a preliminary study, so that the method used are mainly observation in the field and study using multi-disciplinary approach. It is hoped that the cultural heritage conservation is not only dealing with the object, but also paying attention to the surrounding area that could be damaging.
\end{abstract}

Keywords: Conservation, river, site

\section{Latar Belakang}

Pengaruh besar kebudayaan India khususnya dalam pembuatan candi maupun jenis bangunan lainnya (benteng, pemandian dll) di Nusantara, tidak sepenuhnya dicontoh dan diterapkan, melainkan dipadukan dengan local genius masyarakat setempat. Akan tetapi terdapat beberapa hal baku yang tidak bisa diganggu gugat dan tetap dipertahankan. Salah satunya adalah mengenai peran penting dan keberadaan sumber air dalam menentukan lokasi pendirian bangunan. Sepenuhnya hal ini dijelaskan dalam kitab Silpasastra, dan yang menarik adalah semua bangunan suci diusahakan dibangun sedekat mungkin dengan sumber mata air ataupun sungai. Kitab ini juga memaparkan prinsip bentuk, ukuran, warna, ornamen, maupun lokasi yang merupakan dasar-dasar arsitektur yang tertib dan teratur (Sumintardja, 1978). Sejarah mencatat bahwa aliran sungai telah terbukti memiliki peranan penting dalam perkembangan peradaban manusia. Selain fungsinya untuk pemenuhan kebutuhan sehari-hari dan bersuci, air juga dianggap sebagai lambang kehidupan dan kemakmuran. Atas dasar konsep tersebut sangat tidak mengherankan apabila banyak ditemukan bangunanbangunan tinggalan zaman Hindu yang bersentuhan dan berdekatan langsung dengan sumber air dan aliran sungai, baik berupa candi, petirtaan (pemandian), maupun perbentengan (Soekmono, 1974).

Bagai pisau bermata dua, sungai juga memiliki sifat lain yang bersifat merusak, baik secara cepat (bencana) maupun secara perlahan (misalnya erosi dan gerusan). Dilihat dari prosesnya erosi bisa terjadi melalui dua cara, yaitu terjadi secara alami, ini lebih dikenal dengan sebutan erosi alam atau erosi geologis. Erosi kedua adalah erosiyang terjadi akibat tindakan manusia yang disebut dengan erosi dipercepat (Wudianto, 1990: 2). Selain erosi, kerusakan yang ditimbulkan oleh aliran sungai secara perlahan bisa berupa gerusan (scour). Serangan dan gerusan (scour) pada tebing sungai karena meander (berkelok) dapat berakibat 


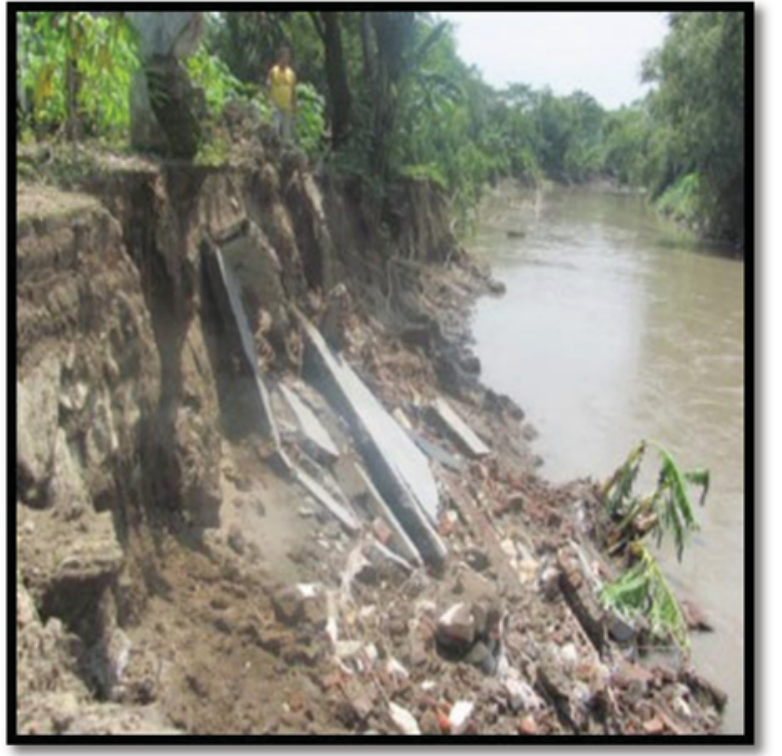

Gambar 1. Erosi pada aliran sungai.

hilangnya tanah berharga; kerusakan tanggul dan jalan, isolasi jembatan dan lain-lain. Gerusan ${ }^{1}$ adalah istilah untuk gerak lateral bahan pada dasar sungai atau dari tebing sungai (Mardjikum, 1979: 2).

Melihat kerusakan yang ditimbulkan aliran sungai bisa diakibatkan oleh banyak faktor, manusia kemudian mulai mengamati dan mempelajari sifat-sifat aliran sungai. Seiring waktu dan berkembangnya ilmu pengetahuan, alur sungai yang kemungkinan memiliki potensi merusak pada akhirnya bisa dikendalikan pada kondisi yang tidak merusak. Upaya pengendalian ini dikenal dengan istilah konservasi daerah aliran sungai atau konservasi DAS. Pada umumnya konservasi DAS dilakukan bertujuan untuk memberikan perlindungan badan sungai, baik palung, bantaran, maupun sempadan sungai, dan pencegahan pencemaran air sungai yang ditujukan untuk mempertahankan kualitas air sungai sesuai dengan peruntukannya (Yulistianto, 2013)². Akan tetapi melihat

1 Gerusan merupakan proses erosi dan deposisi pada sungai yang terjadi karena adanya perubahan pola aliran, terutama pada sungai alluvial. Perubahan bisa diakibatkan oleh beberapa hal yang antara lain adanya rintangan yang menghalngi aliran sungai seperti jembatan, bangunan, atau tumpukan batu berukuran besar. Bangunan yang menghalangi selain dapat mengubah alur sungai, juga diikuti dengan gerusan atau kerusakan disekitar bangunan (Legono, 1990).

2 Pidato pengukuhan guru besar Bambang Yulistianto yang berjudul "Pelestarian dan Pemanfaatan Sungai Secara Terpadu dan Berkelanjutan Bagi Kemaslahatan Manusia". Fakultas Teknik Universitas Gadjah Mada. Yogyakarta, 2013. Hl: 3. banyaknya bangunan cagar budaya yang berlokasi di sepanjang tepian aliran sungai, maka perlu suatu upaya konservasi untuk melindunginya dari pengaruh negatif sungai yang bisa menimbulkan kerusakan.

Upaya konservasi DAS yang berlokasi di sekitar situs merupakan tindakan yang tidak kalah pentingnya dengan konservasi pada situs cagar budaya itu sendiri. Disamping karena efek negatif sungai yang merusak situs, hal ini juga merupakan wujud nyata kepedulian masyarakat akademis 'non-arkeologis' terhadap kelestarian bangunan cagar budaya beserta lingkungan sekitarnya. Pernyataan ini jelas termuat dalam Undang-undang Nomor 11 tahun 2010 BAB I pasal (1) yang berbunyi, cagar budaya adalah warisan budaya yang bersifat kebendaan berupa benda cagar budaya, bangunan cagar budaya, situs cagar budaya, dan kawasan cagar budaya di darat dan/atau di air yang perlu dilestarikan keberadaannya karena memiliki nilai penting bagi sejarah, ilmu pengetahuan, pendidikan, agama, dan/atau kebudayaan melalui proses penetapan ${ }^{3}$.

Perlu diketahui bahwa proses penetapan situs cagar budaya tidak terbatas hanya pada pemerintah pusat, melainkan juga bisa dilakukan oleh Pemerintah Daerah. Hal ini jelas disebutkan pada pasal (96) ayat (1), dimana pemerintah daerah mempunyai wewenang untuk menetapkan, membuat peraturan serta melakukan kerjasama pelestarian cagar budaya ${ }^{4}$. Salah satu Pemerintah Daerah yang telah sadar akan pentingnya pelestarian cagar budaya dan melakukan tanggung jawabnya adalah Kabupaten Lumajang, Provinsi Jawa Timur. Berawal dari kepedulian masyarakat yang kemudian mengajak Pemerintah Daerah Lumajang untuk turut melestarikan situs Biting secara bersama-sama. Hal ini terbukti dari dikeluarkannya surat resmi Pemerintah Kabupaten Lumajang dengan Nomor: 188.45/41/427.12/2011 tentang pembentukan Tim Pelestarian dan Perlindungan Benda Cagar Budaya oleh Wakil Bupati (selaku Plt. Bupati Lumajang) Drs. H. As'at M.Ag. Dengan adanya surat keputusan yang menetapkan situs Biting ${ }^{5}$

\footnotetext{
3 Undang-Undang Cagar Budaya No. 11 Tahun 2010.

4 Ibid.

5 Berupa kawasan benteng tanah seluas 135 ha yang keemapat sisinya juga dilindungi aliran sungai. Lokasi benteng terletak di Kabupaten Lumajang.
} 


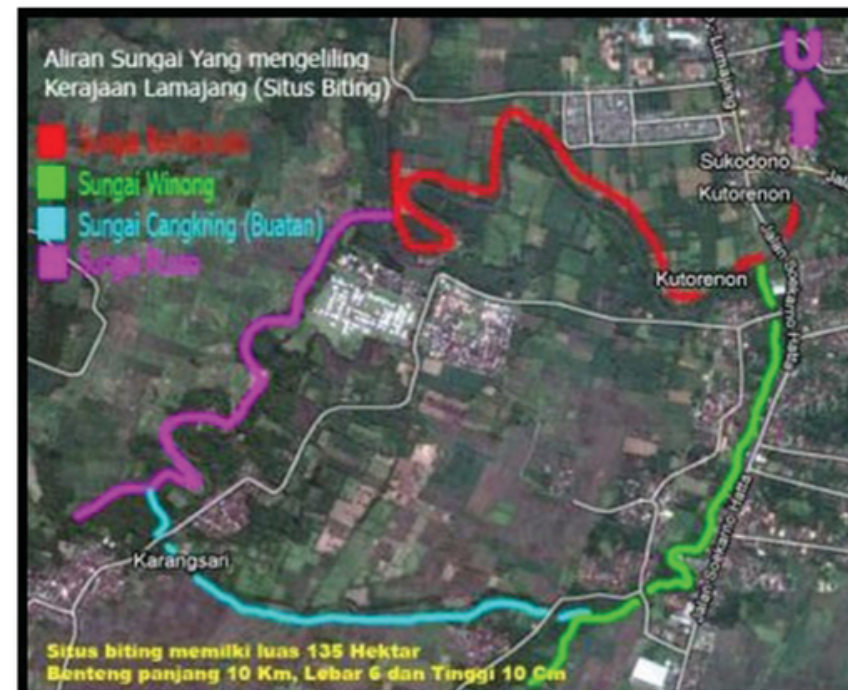

Gambar 2. Peta Situasi Situs Biting, Kabupaten Lumajang. Sumber: Olah Data Google Earth.

sebagai cagar budaya, dan dibentuknya tim pelestarian situs Biting, maka semakin memperkuat keberadaan situs Biting sebagai BCB yang harus dilestraikan.

Perlu diketahui, bahwa sejauh ini tindakan dan upaya pelestarian yang dilakukan pada situs Biting baru pada sebatas ekskavasi dan inventarisasi hasil ekskavasi yang dilakukan oleh pihak Balai Arkeologi Yogyakarta ${ }^{6}$. Sedangkan tindakan konservasi pada situs Biting belum dilakukan, terlebih lagi pada lingkungan sekitarnya yang berpotensi merusak situs, yakni aliran sungai yang secara langsung berbatasan dengan situs Biting.

Melihat kenyataan di lapangan pada kunjungan penulis untuk yang ke dua kalinya di situs Biting ${ }^{7}$, penulis menyimpulkan bahwa perlu adanya upaya konservasi pada situs Biting, dan terlebih penting lagi konservasi pada aliran sungai yang kian menggerus dan merusak dinding situs Biting. Oleh karena permasalahan tersebut, maka penulis merasa perlu untuk membuat sebuah tulisan kecil mengenai konservasi DAS pada situs Biting, sekaligus mengajak semua masyarakat akademis untuk melakukan tindakan konservasi yang tidak hanya menekankan pada

6 Pada BPA (Berita Penilitian Arkeologi) Balai arkeologi Yogyakarta dan dan artikel-artikel yang pernah diterbitkan oleh pihak-pihak terkait, termasuk BP3 Jawa Timur.

7 Kunjungan I dilakukan dalam rangka seminar nasional mengenai nilai penting kawasan situs Biting, sedangkan kunjungan ke-II pada acara napak tilas II yang diselenggrakan di kawasan situs Biting tertanggal 7-8 Juli 2012.

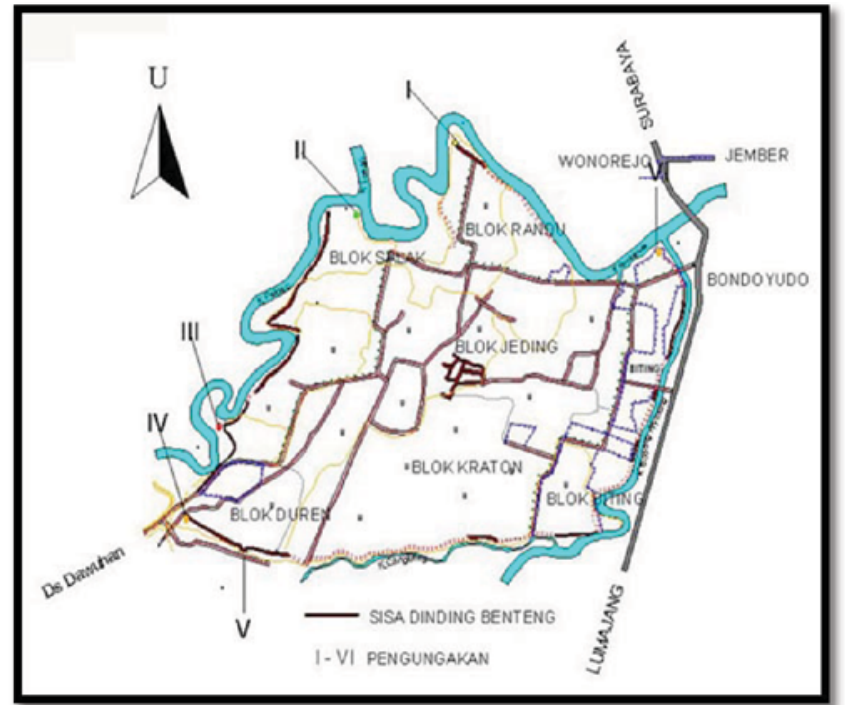

Gambar 3. Kawasan situs Biting dikelilingi empat aliran sungai. Sumber: BALAR Yogyakarta.

situs cagar budaya, akan tetapi juga pada lingkungan sekitar situs.

\section{Gambaran Umum Situs Biting Kabupaten Lumajang}

Kabupaten Lumajang merupakan salah satu kabupaten yang berlokasi di Propvinsi Jawa Timur. Kabupaten ini terletak pada posisi $7^{\circ} 52^{\prime} \mathrm{s} / \mathrm{d} 8^{\circ} 23^{\prime}$ Lintang Selatan dan $112^{\circ} 50^{\prime}$ s/d $113^{\circ} 22^{\prime}$ Bujur Timur. Dengan Luas wilayah 1.790,90 $\mathrm{Km}^{2}$ atau 3,74\% dari luas Propinsi Jawa Timur. Secara administratif batas-batas wilayah kabupaten Lumajang adalah sebagai berikut: sebelah utara berbatasan dengan Kabupaten Probolinggo, sebelah timur berbatasan dengan Kabupaten Jember, sebelah selatan berbatsan dengan Samudera Indonesia, sebelah barat berbatasan dengan Kabupaten Malang (BPS, 2012).

Adapun gambaran umum jumlah penduduk Kabupaten Lumajang berdasarkan data sensus penduduk tahun 2010 1.006.458, yakni terdiri atas 491.521 lakilaki dan 514.937 perempuan. Dengan laju pertumbuhan penduduk sebesar 0,419 persen pertahun dan Sex Ratio sebesar 95,45 yang penduduknya tersebar pada 21 kecamatan (BPS, 2012). Sedangkan jumlah penduduk Dusun Biting berdasarkan data sensus 2009 adalah berjumlah 550 jiwa, dengan jumlah penduduk berjenis kelamin laki-laki sebanyak 189 dan perempuan berjumlah 237 jiwa. 


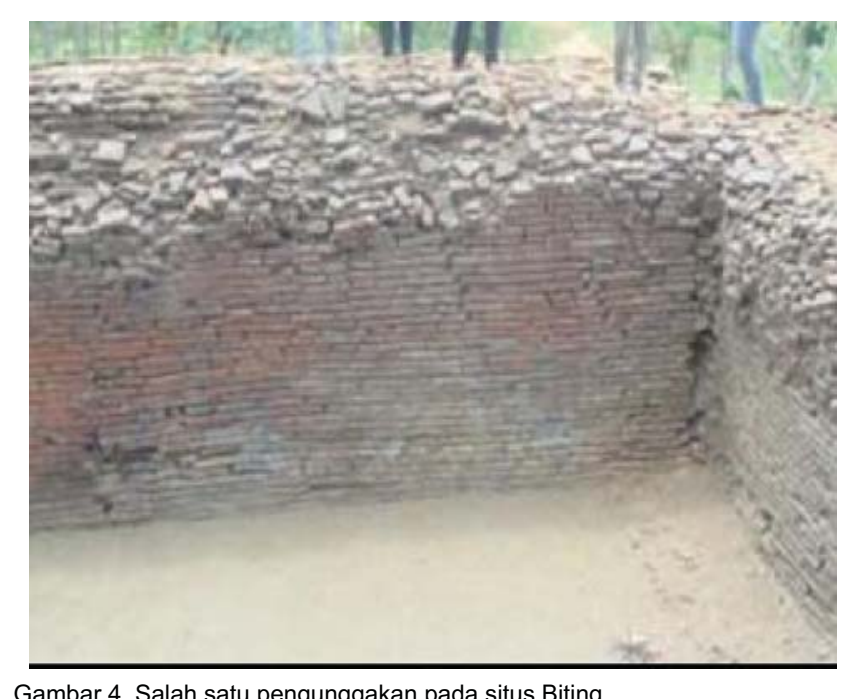

Gambar 4. Salah satu pengunggakan pada situs Biting.

Secara administratif Situs Biting terletak di Dusun Biting, Desa Kutorenon, Kecamatan Sukodono, Kabupaten Lumajang Provinsi Jawa Timur. Mayoritas penduduk Lumajang didominasi etnis Madura. Kata Biting sendiri berasal dari bahasa Madura yang berarti 'benteng', atau tembok untuk pertahanan bagi kota raja. Selayaknya sebuah benteng kota, situs Biting meliputi areal yang terdiri dari pemukiman, pusat pemerintahan kerajaan, persawahan dan lain sebagainya. Keberadaanya sebagai kota kuno diperkuat dengan temuan arkeologi berupa pondasi bangunan, juga yang diperkirakan bekas keraton.

Adapun luas situs secara keseluruhan diperkirakan mencapai 135 ha, yang dibagi menjadi 6 blok. Lingkungan situs Biting sendiri dikelilingi oleh 4 aliran sungai, yaitu pada sebelah Utara terdapat sungai Bondoyudo, pada bagian Timur terdapat Sungai Winong atau Bodang, sebelah Selatan terdapat sungai terdapat Sungai Cangkringan, dan pada bagian Barat adalah Sungai Ploso. Dimana pada masing-masing tepian sungai terdapat benteng tanah bentukan bercampur bata dengan ketebalan sekitar 1.60 $\mathrm{m}$ dengan tinggi sekitar $2 \mathrm{~m}$. Bekas benteng kota ini juga terdiri dari beberapa menara intai yang terbuat dari bata berukuran besar, dengan menggunakan spesi atau perekat berupa tanah tanpa lepa. Menara intai berdenah segi empat, yang oleh penduduk setempat disebut sebagai pengungakan, dan teridiri dari pengungakan I sampai VI (Lihat Gambar 4) ${ }^{8}$.

8 Gambar 4 merupakan salah satu pengungakan atau
Dari enam pengungakan tersebut, tiga di antaranya terletak di sisi barat, sementara di ketiga sisi lainnya juga masing-masing terdapat sebuah pengungakan. Dari pengungakan yang masih tampak relatif utuh, yaitu pengungakan I dan II diketahui bahwa luas masing-masing adalah $7.5 \mathrm{~m}$ x $6.5 \mathrm{~m}$ dengan tinggi antara $3.8 \mathrm{~m}-8 \mathrm{~m}$ (Abbas, 1992).

Menyangkut hasil penelitian arkeologi di lokasi situs Biting, selain tembok bata juga ditemukan artefak lainnya baik berupa pecahan tembikar, keramik, mata uang, alat logam, maupun batu-batu bulat. Pecahan-pecahan tembikar setelah dianalisis menunjukkan berbagai bentuk wadah, seperti periuk, buyung (klenthing), kendi, mangkuk, cawan, piring, pengaron, dan kowi. Analisis terhadap temuan pecahan keramik menunjukkan bentuk asal berupa mangkuk, buli-buli, cepuk, cangkir, piring, dan guci (Abbas, 2012).

\section{Konservasi DAS $^{9}$ Dalam Upaya Perlindungan Situs Biting}

Kabupaten Lumajang merupakan wilayah yang tergolong cukup luas, yakni $1.790,90 \mathrm{~km}^{2}$, dan terbagi dalam 21 kecamatan yang memiliki beberapa DAS (Daerah Aliran Sungai). Diantara beberapa DAS tersebut, terdapat satu DAS yang melintasi wilayah situs Biting yang terdiri dari satu sungai induk dan beberapa anak sungai. Secara alami sungai induk dan beberapa anak sungai tersebut mengelilingi kawasan perbentengan situs Biting. Adapun empat aliran sungai tersebut yakni: (1) Sebelah utara terdapat Sungai Bondoyudo sebagai sungai induk; (2) Bagian Timur Sungai Winong atau Bodang; (3) Di sebelah Selatan Sungai Cangkringan; (4) Pada bagian Barat terdapat Sungai Ploso. Masing-masing sungai ini memiliki potensi merusak dinding benteng baik secara langsung pada saat terjadi luapan air, maupun secara

9 DAS atau Daerah Aliran Sungai menurut UU No. 7 Tahun 2004, adalah satu wilayah daratan yang merupakan satu kestuan dengan sungai dan anak-anak sungainya, yang berfungsi menampung, menyimpan dan mengalirkan yang berasal dari curah hujan ke danau atau ke laut sampai dengan daerah perairan yang masih terpengaruh aktifitas daratan. Sedangkan sungai adalah air yang mengalir secara alamiah melalui sebuah saluran alam. Jadi yang membedakan aliran sungai dengan DAS adalah luasan kawasan dan banyaknya aliran sungai. 


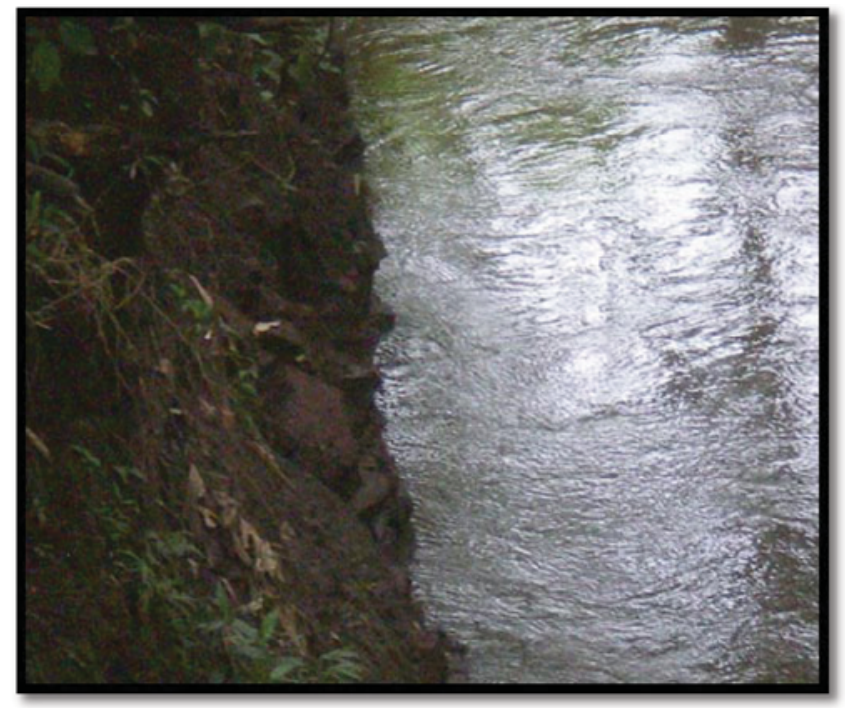

Gambar 5. Sungai Bondoyudo berbatasan langsung dengan dinding benteng yang mulai tergerus. Sumber: Pribadi.

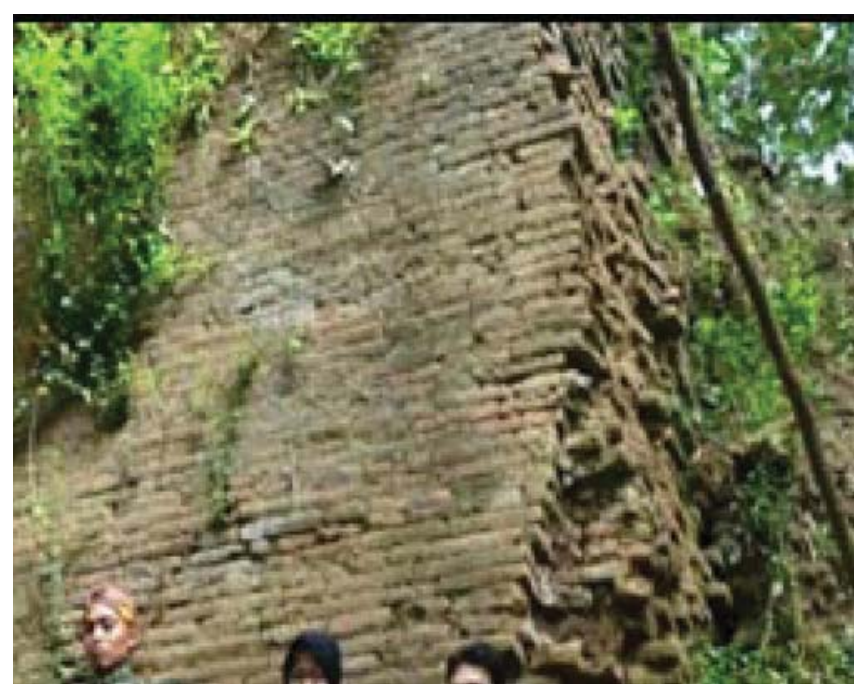

Gambar 6. Tembok benteng dekat aliran sungai yang rusak akibat longsoran tanah.

perlahan dalam bentuk pengikisan dinding benteng yang terbuat dari tanah bentukan dengan struktur bata (lihat gambar 5 dan 6).

Benteng Biting berdenah asimetris, yakni dibentuk dengan mengikuti bentuk empat aliran sungai yang terdapat di lokasi tersebut, yaitu Sungai Bondoyudo di sisi utara, Sungai Winong di sisi timur, Sungai Cangkring di sisi selatan, dan Sungai Ploso di sisi barat. Sementara posisi keenam pengungakan benteng ini masing-masing terdapat pada kelokan sungai. Perlu diketahui bahwa sungai yang terletak di sebelah selatan, yaitu Sungai Cangkringan, merupakan sungai buatan. Sedangkan di sebelah barat daya terdapat bekas-bekas pembendungan Sungai Ploso (Moelyadi, 1983 ).
Beberapa penelitian terdahulu di bidang keilmuan teknik sipil menunjukkan bahwa sungai dan anak sungai yang mengaliri Dusun Biting tersebut memiliki aliran air yang bertenaga cukup kuat. Beberapa tahun yang lalu, pihak Fakultas Teknik ITS (Institut Teknologi Sepuluh November) melakukan suatu penelitian mengenai sungai dan anak sungai yang melintasi Dusun Biting dengan judul "Analisis Groundwater Storage Daerah Aliran Sungai Bondoyudo Kabupaten Lumajang Menggunakan Metode Neraca Air". Adapun gambaran singkat dari hasil penelitian tersebut menyebutkan bahwa, sungai Bondoyudo memiliki luas daerah aliran 1, $341 \mathrm{~km}^{2}$ yang mencakup hampir keseluruhan luas Kabupaten Lumajang. Penelitian yang dilakukan dengan memakan kurun waktu selama empat tahun yakni, dari tahun 2004 hingga tahun 2007, bertujuan untuk mengetahui siklus hidrologi di daerah DAS tersebut ${ }^{10}$. Berdasarkan hasil evaluasi penelitian, disimpulkan bahwa curah hujan yang cukup tinggi terjadi pada wilayah Kabupaten Lumajang ${ }^{11}$. Curah hujan yang tinggi tersebut sering mengakibatkan terjadinya luapan air sungai sekaligus membawa materialmaterial lain yang mengakibatkan pengendapan di sekitar dinding sungai (Tatas, 2009).

Kesimpulan hasil penelitian yang pernah dilakukan pihak ITS tersebut diperkuat dengan data curah hujan yang dirangkum oleh Badan Pusat Statistik Kabupaten Lumajang. Bahwa curah hujan tahunan pada wilayah Lumajang berkisar antara $1.500-2.500 \mathrm{~mm}$ per tahun, sehingga berakibat sering terjadi luapan air dan pengikisan pada dinding sungai secara terus menerus. Melihat hasil kesimpulan penelitian ITS (Institut Teknologi Sepuluh Nopember) dan dibandingkan dengan pengamatan di lapangan, sangat jelas terlihat adanya pengikisan dinding sungai yang berdampak semakin menipisnya luasan jarak antara dinding benteng dengan aliran sungai ${ }^{12}$. Bahkan di bagian lain sudah tidak tersisa jarak dinding benteng dengan aliran sungai. Apabila hal ini terus dibiarkan, maka

10 Sungai Bondoyudo merupakan induk sungai yang melintasi wilayah Lumajang, termasuk Dusun Biting dengan beberapa anak sungai yang mengelilingi kawasan situs Biting. Adapun perbedaan antara DAS dengan aliran sungai telah dijelaskan dalam pemaparan sebelumnya.

11 Hujan rata-rata tahunan berkisar 3251, $46 \mathrm{~mm}$

12 Terlihat pada gambar 5 , aliran sungai semakin mengikis dan memperkecil jarang antara dinidng benteng dengan aliran sungai. 
dalam jangka waktu dekat pengikisan dinding benteng akan semkin parah, dan bisa mengakibatkan terjadinya keruntuhan. Untuk mengatasi kemungkinan kerusakan, perlu adanya tindakan konservasi daerah aliran sungai (DAS) yang melintasi kawasan situs Biting.

Pada awalnya konservasi terbatas pada pelestarian atau pengawetan monumen bersejarah yaitu dengan mengembalikan, mengawetkan monumen tersebut persis seperti keadaan di masa lampau. Konsep ini kemudian berkembang, sehingga konservasi tidak hanya mencakup monumen atau benda arkeologis saja, melainkan juga diterapkan pada lingkungan, taman, dan bahkan kota bersejarah. Bila dilihat secara defenisi, pengertian konservasi seperti yang disepakati dalam Piagam Burra ${ }^{13}$, merupakan segenap proses pengelolaan suatu tempat agar makna kultural yang dikandungnya terpelihara dengan baik. Konservasi dapat meliputi seluruh kegiatan pemeliharaan dan sesuai dengan situasi dan kondisi setempat, dapat pula mencakup preservasi, restorasi, rekonstruksi, adaptasi, dan revitalisasi (Sidharta, 1989: 9 ). Sedangkan apabila ditinjau menurut UU No. 11 Tahun 2010 tentang cagar budaya, maka konservasi merupakan suatu upaya dinamis untuk mempertahankan keberadaan Cagar Budaya dan nilainya dengan cara melindungi, mengembangkan, dan memanfaatkannya ${ }^{14}$.

Dalam kajian ini, upaya konservasi secara spesifik dititikberatkan pada aliran sungai di sekitar kawasan Situs Biting. Apabila ditinjau secara definisi, konservasi aliran sungai memiliki pemaknaan yang berbeda dengan pengertian konservasi dalam lingkup kajian arkeologi. Adapun pengertian konservasi sumber daya air yang dijelaskan pada UU No. 7 Tahun 2004, yakni konservasi sumber daya air adalah upaya memelihara keberadaan serta keberlanjutan keadaan, sifat dan fungsi sumber daya air agar tetap senantiasa tersedia dalam kuantitas dan kualitas yang memadai untuk memenuhi kebutuhan makhluk hidup, baik pada waktu sekarang maupun yang

13 Piagam Burra atau Burra Charter merupakan piagam yang menetapkan standar konservasi dan restorasi benda cagar budaya yang dikeluarkan oleh ICOMOS (International Council on Monument and Sites), yang kedudukannya berada dibawah UNESCO.

14 Undang-Undnag No. 11 Tahun 2010. BAB I (Ketentuan Umum), pada pasal (1) poin ke 22. akan datang ${ }^{15}$. Mengingat pentingnya fungsi dan peran sumber daya air seperti yang telah di jelaskan dalam undang-undang, maka dalam pengelolaan wilayah sungai diperlukan perencanaan, pengaturan, pengembangan, dan pemanfaatan sumber-sumber air secara terpadu dan meneyeluruh. Istilah yang dipakai adalah one river basin one plan (Ongkosongo, 2010). Secara terpadu dan menyeluruh dapat diartikan dengan melakukan kajian yang melibatkan bidang keilmuan terkait lainnya. Seperti halnya dalam kasus ini, dimana kajian arkeologi hendaknya melibatkan bidang keilmuan hidrologi untuk menghasilkan upaya konservasi DAS pada kawasan Situs Biting secara maksimal.

\section{Langkah dan Tindakan Konservasi DAS Kawasan Situs Biting}

Wilayah perbentengan seluas 135 ha, Situs Biting dirancang oleh seorang arsitek yang dalam sejarah disebut sebagai Arya Wiraraja. Secara strategi militer, Arya Wiraraja memilih tempat yang tepat dengan medan strategis dan kondisi di dalam benteng yang merupakan permukaan datar dan subur. Dia juga memperkuat benteng dengan dinding bata setinggi dua meter dengan ketebalan 1, 60 $\mathrm{cm}$. Cetakan batu bata berukuran cukup besar dengan pembakaran bersuhu tinggi dan menggunakan perekat atau spesi berupa tanah tanpa lepa (Abbas, 1992)

Pada dasarnya aliran sungai yang mengelilingi kawasan Situs Biting telah terbentuk secara alami sebelum benteng kota didirikan oleh Arya Wiraraja. Dalam hal ini terlihat bahwa aliran sungai memiliki multi fungsi, yang juga bisa dimanfaatkan sebagai benteng pertahanan. Dimasa lampau aliran sungai ini berperan sebagai pelindung, namun dimasa kini ternyata aliran sungai tersebut justru menjadi ancaman terhadap benteng yang didirikan dengan mengikuti pola aliran sungai. Sehingga yang menjadi perhatian utama dan diangggap paling mengkhawatirkan serta harus segara ditangani adalah dinding benteng Situs Biting dan pengungakan (menara intai). Hal ini diperkuat dengan pengamatan di lapangan bahwa kemungkinan besar aliran sungai akan terus menerus menggerus dan merusak dinding benteng serta tanah pondasinya.

\footnotetext{
15 Undang-Undang No. 7 Tahun 2004 tentang Sumber
} Daya Air. 


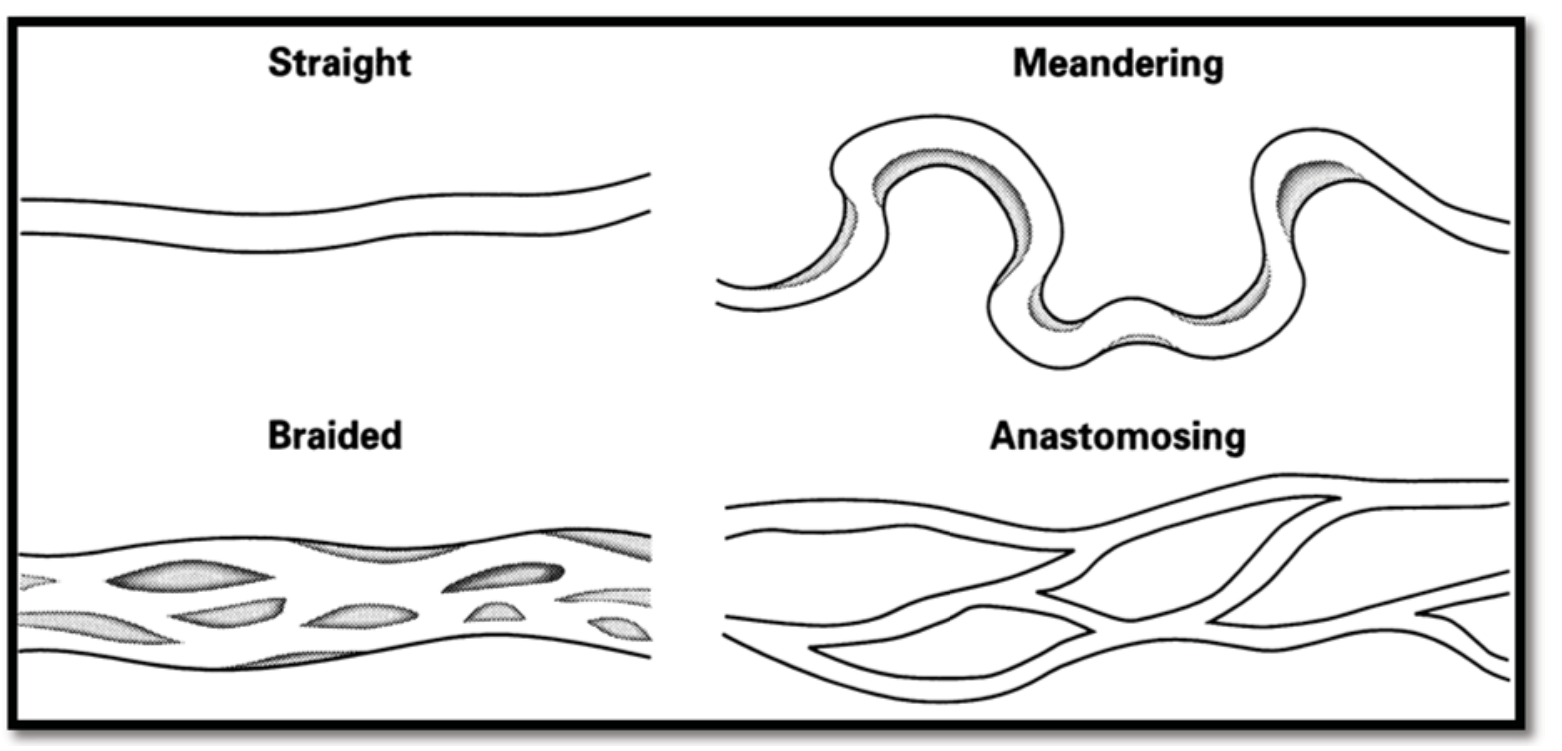

Gambar 7. Tipe alur sungai memanjang, meanders, braided, dan anstomosing (Rosgen, 1996)

Meskipun secara sekilas sungai terlihat memiliki aliran yang sulit diprediksi, namun dengan pengamatan dan peneltian dalam kurun waktu yang lama, maka sungai juga dapat dimengerti sebagai sistem yang teratur. Sistem yang teratur ini diartikan bahwa segala jenis komponen penyusun sungai memiliki karakteristik yang teratur atau dapat dikaji dan diperidiksi. Karakteristik ini menggambarkan kondisi spesifik sungai yang bersangkutan. Sistem sungai alamiah merupakan sistem sungaiyang teratur dan komplek yang setiap komponennya saling berpengaruh satu sama lain (Maryono, 2007: 8).

Melihat alur sungai yang mengelilingi Situs Biting, diperkirakan alur sungai bertipe lurus memanjang dan meander atau dengan alur sungai berkelok. Untuk memperjelas analisis model alur sungai pada Situs Biting, maka dilakukan perbandingan kondisi di lapangan dengan tipe alur sungai menurut Rosgen ${ }^{16}$ seperti pada Gambar 7.

Melihat pola sungai memanjang atau meander akan menetukan pengambilan langkah konservasi yang paling aman dan tepat bagi benteng tanah situs Biting dan juga lingkungan sekitarnya. Adapun langkah konservasi yang diambil dalam upaya perlindungan dan pengurangan kerusakan pada dinding benteng kawasan Situs Biting adalah sebagai berikut:

16 Dikutip dari buku berjudul Restorasi Sungai 'River Restoration (Maryono, 2007).

\section{AMDAL (Analisis Dampak Lingkungan)}

Tindakan awal yang akan ditempuh oleh konservator dalam kasus benteng kawasan Situs Biting seluas 135 ha adalah AMDAL atau Analisis Dampak lingkungan. Pengkajian mendalam perlu dilakukan untuk mengetahui sejauh mana pengaruh yang muncul pada biota sungai maupun kehidupan yang terkait dengan aliran sungai yang mengelilingi benteng. Walau bagaimanapun pentingnya BCB yang dalam hal ini benteng Situs Biting untuk dipertahankan kelestariannya, namun keseimbangan dan kelestarian alam tidak kalah penting untuk tetap dijaga. Untuk pengkajian AMDAL, perlu dibentuk satu tim kecil yang memang ahli dan berpengalaman dalam bidang tersebut.

\section{Pembuatan DAM}

Pada beberapa bagian wilayah sungai yang mengelilingi benteng kawasan Situs Biting perlu dibuat DAM berukuran kecil yang disesuaikan dengan besarnya sungai dan debit air sungai pada musim penghujan guna mangatur daya rusak aliran sungai. Hal ini juga dilakukan sebagai kontrol air pada musim-musim tertentu untuk menghindari luapan berlebih yang mengakibatkan terjadinya banjir sehingga menggenangi wilayah dinding benteng.

Dalam upaya kegiatan konservasi yakni penambahan jarak pembatas antara sungai dengan dinding benteng, maka aliran sungai untuk sementara akan diperkecil 
debitnya, sehingga pembuatan DAM pada beberapa titik akan sangat membantu pengerjaan proyek tersebut.

\section{Penanganan Dampak Negatif Sungai}

Dalam kaitan dengan bencana bersumber dari air, terdapat beberapa konsep penanganan dampak negatifnya, yakni antara lain sebagai berikut:

\section{Pengelolaan dataran banjir (flood plain management)}

Mitigasi perusakan akibat banjir (flood demage mitigation)

Perlawanan banjir (flood fighting)

Pengelolaan perusakan akibat banjir ( flood demage management)

Penangananan setelah banjir (post flood disaster relief)

Pengelolaan dataran banjir dimaksudkan untuk menghindari atau memperkecil dampak pada wilayah sekitar. Wilayah tepian sungai ${ }^{17}$ pada kenyataannya sering digunakan sebagai tempat tinggal dan infrastruktur terbangun lainnya (Ongkosongo, 2010: 11). Dalam hal ini juga termasuk wilayah benteng Situs Biting yang terkena genangan akibat luapan dari beberapa sungai yang mengelilinginya. Apalagi mengingat sungai-sungai ini $^{18}$ adalah sungai yang memiliki aliran terus menerus sepanjang tahun (continuous flow) dan dapat berubah menjadi sungai aliran curah hujan karena pengelolaan daerah hulu yang buruk sehingga pada waktu musim hujan kemungkinan akan terjadi banjir (Ongkosongo, 2010: 164).

\footnotetext{
17 Wilayah yang dimaksud adalah wilayah tepian sungai pada umumnya.

18 Sungai yang dimaksud adalah sungai yang beraliran deras.
}

\section{Daftar Pustaka}

Abbas, Novida. 1992. Laporan Hasil Penelitian Arkeologi Situs Biting, Kelurahan Kutorenon, Kecamatan Sukodono, Kabupaten Lumajang, Jawa Timur Tahap XI. Balai Arkeologi Yogyakarta. Yogyakarta.

\section{Penutup}

Dalam kasus permasalahan kerusakan BCB (Benda Cagar Budaya) yang dikaibatkan oleh sungai memang masih kurang mendapatkan perhatian dari kalangan arkeolog. Namun persinggungan $\mathrm{BCB}$ dengan DAS terbilang cukup banyak dijumpai di lapangan, terlebih pada BCB peninggalan zaman Hindu-Budha. Salah satu contoh kasus yang cukup menarik dan perlu penanganan segera adalah benteng tanah situs Biting di Dusun Biting Kabupaten Lumajang. Selama ini pusat perhatian arkeologi Yogyakarta masih tertumpu pada pengkajian dan penggalian artefaktual yang berada didalam kawasan benteng (objek arkeologis) dan melupakan keberadaan di luar benteng, yakni sungai yang bersinggungan langsung dengan dinding benteng yang semakin rusak karena terus menerus digerus sungai yang mengelilingi empat sisinya.

Sejauh ini belum ada tindakan konservasi yang diakukan pada benteng tanah Situs Biting, hal itulah yang menjadi alasan penulis untuk mengangkat tema tulisan konservasi DAS dalam upaya perlindungan kerusakaan pada dinding benteng Situs Biting. Model usulan dan langkah-langkah konservasi yang ditawarkan penulis masih terbilang jauh dari sempurna, namun harapannya dengan adanya tulisan ini akan sedikit membuka mata dan menyadarkan kita untuk berpaling sejenak keluar benteng, melihat sungai dan dinding benteng yang semakin tergerus dan rusak akibat tidak adanya pengelolaan sungai sehingga membawa dampak negatif pada situs.

Legono, D. 1990. Gerusan Pada Bangunan Sungai. PAU Ilmu-Ilmu Teknik UGM. Yogyakarta.

Mardjikum, Pragnjono. 1979. Teknik Sungai "Diktat Kuliah”. Fakultas Teknik Universitas Gadjah Mada. Yogyakarta. 
Maryono, Agus. 2007. Restorasi Sungai "River Restoration". Fakultas Teknik Universitas Gadjah Mada. Yogyakarta.

Moelyadi. 1983. Dampak Lingkungan Geologi terhadap Pendirian dan Kehancuran Kerajaan Lama Sukodono, Lumajang, Jawa Timur. Jurusan Teknik Geologi Fakultas Teknik Universitas Gadjah Mada. Yogyakarta.

Ongkosongo, Otto S.R. 2010. Kuala, Muara Sungai dan Delta. Lembaga Ilmu Pengetahuan Indonesia (LIPI). Jakarta.

Purwantiny, Aries. 2012. Peradaban Lamajang kuno. Putra Media Nusantara. Surabaya.

Sidharta. 1989. Konservasi Lingkungan dan Bangunan Kuno Bersejarah di Surakarta. Gadjah Mada University Press. Yogyakarta.

Soekmono. 1974. Candi, Fungsi dan Pengertiannya 'Disertasi'. Fakultas Sastra Universitas Indonesia. Jakarta.

Sumintardja, Djauhari. 1978. Kompendium Sejarah Arsitektur. Yayasan Lembaga Penyelidikan Masalah Bangunan. Bandung.

Tatas. 2009. Analisis Groundwater Storage Daerah Aliran Sungai Bondoyudo Kabupaten Lumajang Menggunakan Metode Neraca Air. Diploma 3 Fakultas Teknik Sipil. Institut Teknologi 10 November. Surabaya.
Wudianto, Rini. 1990. Mencegah Erosi. Penebar Swadaya. Jakarta.

Yulistianto, Bambang. 2013. Pelestarian dan Pemanfaatan Sungai Secara Terpadu dan Berkelanjutan Bagi Kemaslahatan Manusia "Pidato Pengukuhan Guru Besar". Fakultas Teknik Universitas Gadjah Mada. Yogyakarta.

\section{Perundangan}

Undang-undang No. 11 Tahun 2010 tentang Cagar Budaya

Undang-undang Nomor. 7 Tahun 2004 tentang Sumber Daya Air

Undang-Undang Nomor. 32 tahun 2004 tentang Pemerintahan Daerah

Surat Keputusan Nomor : 188.45/41/427.12/2011 tentang Tim Pelestarian dan Perlindungan Benda Cagar Budaya di Kabupaten Lumajang

Piagam Burra (Burra Charter) ICOMOS 1981. 